\title{
Inclusive education: an examination of school relationships and student interactions
}

\author{
Angelina Sánchez-Martí \\ Department of Methods of Research and Diagnostics in Education (MIDE), University \\ of Barcelona, Barcelona, Spain \\ Vall d'Hebrón, 171, Edifici de Llevant. Facultat de Pedagogia. 08035 Barcelona (Spain) \\ +34934035248 angelinasanchez@ub.edu
}

\author{
Alma A. Ramírez-Iñiguez \\ Department of Methods of Research and Diagnostics in Education (MIDE), University \\ of Barcelona, Barcelona, Spain \\ Vall d'Hebrón, 171, Edifici de Llevant. Facultat de Pedagogia. 08035 Barcelona (Spain) \\ +34934035248 almarceliar@gmail.com
}

Angelina Sánchez Martí is a research scholar and Doctoral student in Education and Society, University of Barcelona (UB). She holds a Master in Educational Psychology and a Research Master's degree in Citizenship and Values Education, both awarded by the Faculty of Education (UB). She is currently writing her doctoral thesis on successful academic transitions of immigrant students into higher education using Social Network Analysis.

Alma Arcelia Ramírez Iñiguez is a Doctoral student in Education and Society, University of Barcelona. She is a research scholar, National Council of Science and Technology (CONACYT), Mexico. Her professional career has focused mainly on the assessment of educational programmes and of teaching in the area of higher education. She is currently writing her doctoral thesis on schools as a social inclusion factor relating to migrant child labourers in Mexico. Her lines of research include inclusive education, education for vulnerable groups and migration. 


\title{
Inclusive education: an examination of school relationships and student interactions
}

\begin{abstract}
The aim of this paper is to examine inclusive education in multicultural contexts from an interaction networks perspective. The paper is based on the idea that inclusive education can be better understood by studying how native and non-native students interact and what kinds of networks they establish in school. To do so, we assume two premises: (a) class-group dynamics can have a socially inclusive impact; and, (b) the composition of classroom social networks often play a significant role in educational achievement, especially in classes with students with different cultural backgrounds. Starting from these premises, we firstly discuss the relevance of research and theory on social and personal networks regarding both social inclusion and academic performance. We subsequently review recent literature on "social support" as a factor that is directly related to the inclusion of minority cultural groups in school. We then discuss the importance of the relationships developed among them and their influence on academic performance. School relationships - student networks in and out of school and classroom dynamics - can be developed and shaped in many different ways and across numerous opportunities to enhance educational performance in inclusive multicultural environments.
\end{abstract}

Keywords: inclusive education; social networks; educational achievement; multiculturalism; intercultural contact.

Resumen: El objetivo de este trabajo es examinar la educación inclusiva en contextos multiculturales desde la perspectiva de la interacción de redes. El artículo destaca la idea de que la educación inclusiva puede ser mejor entendida al aprender cómo los estudiantes nativos y no nativos, interactúan y qué tipo de redes establecen en la escuela. Para ello, se suponen dos premisas: (a) las dinámicas del grupo-clase pueden tener un impacto socialmente inclusivo, y (b) la composición de las redes sociales en el aula a menudo desempeña un papel importante en el logro educativo, especialmente en aquellos que son estudiantes de origen cultural diferente. Sobre estas premisas, en primer lugar, se discute la pertinencia de la investigación y la teoría de las redes sociales y personales tanto en relación a la educación inclusiva como al rendimiento académico. Sobre esta base, se revisa literatura reciente sobre el "apoyo social" como un factor que está directamente relacionado con la inclusión de los grupos culturales minoritarios en 
la escuela. En segundo lugar, se discute la importancia de las relaciones desarrolladas entre ellos y su influencia en el rendimiento académico. A lo largo del análisis, se destaca que las relaciones de la escuela -las redes de los estudiantes dentro y fuera del centro junto con las dinámicas escolares- pueden ser desarrolladas y modificadas de muchas maneras en términos de oportunidades para mejorar el rendimiento académico de los alumnos en entornos multiculturales inclusivos.

Palabras clave: educación inclusiva, redes sociales, logro educativo, multiculturalismo, contacto intercultural.

\section{Introduction}

Contemporary international migration is changing societies rapidly. While millions of people are seeking work, others are in search of a new home or a safe place to live far away from their countries of birth. Migratory movements are reflected in classrooms whose students mirror societal diversity. This increasing student diversity can influence social structures in schools and demands a focus on until now unexplored perspectives the impact of migration.

UNESCO's answer is that cultural diversity must be addressed from an inclusive point of view which involves a change in how we think about education. The full appliance of this principle -inclusive education- foresees, at least, two clear outcomes: equality and quality for all. On the one hand, the whole education system must facilitate learning environments where teachers and learners embrace and welcome the challenge and benefits of diversity, reducing exclusion within and from education. On the other hand, individual needs must be met and every student needs to have an opportunity to succeed through enhancing the quality of education (UNESCO 2001).

According to UNESCO, in order to achieve the benefits of inclusive education, a radical reform of the school in terms of educational policy and curricular frameworks is needed. This reform can be accomplished by:

(1) Improving teacher effectiveness,

(2) Promoting learning-centred methodologies,

(3) Developing appropriate textbooks and learning materials,

(4) Ensuring that schools are safe and healthy for all children, and

(5) Strengthening links between teachers, students, parents and society at large.

Despite all these measures, the authors are particularly concerned by the change at the level of social processes and structures. That is why in this paper we focus our attention on a component we believe to be crucial for developing inclusive learning environments: school relationships and student interactions. In so doing, we want to demonstrate the value of a social network approach when examining to what extent classroom dynamics can have a socially inclusive impact. We believe that learning how native and non-native students interact and what kind of networks they establish in school will provide us with clues and directions that will help us rethink our practice and keep moving towards inclusive education goals. 
In this paper we first examine the relevance of theory and research on social and personal networks. We outline the social network approach and identify some key studies related to this. Subsequently, we discuss the importance of social networks when analyzing the consequences of migration in schools. In particular, our focus is on social inclusion and academic performance. Existing studies show that social network techniques provide insight into inclusive education in multicultural contexts. Moreover, they show that social networks play a significant role in educational achievement, especially in schools and classes with students from different cultural backgrounds.

\section{Theory and research on social and personal networks}

During the last few years, particularly in Spain, there has been growing research related interest in the composition of social networks, mainly concerning disadvantaged groups such as immigrants. Many studies have used the theoretical and methodological approach known as "Social Network Analysis" (SNA) to address their research questions. This approach moves from an attributive conception (the person as a sum of factors: age, gender, cultural group identity, etc.) to a more complex one that takes into consideration the structure and functionality of the links that persons establish with others, groups, associations etc. This does not necessarily mean researchers exclude individual attributes from their studies, but they usually examine them separately.

Briefly, the social network approach is based on the study of interactions among individuals (or organizations) (Freeman 2004). These interactions may result in the formation of relationships which, when linked with others, form social networks. Thus, social networks consist of nodes and ties. Nodes are the individual actors or units within the networks, and ties (or links) are the relationships between the actors. These concepts are often displayed in a social network diagram, where the nodes are points and the ties are lines. As one might think, complete networks operate on many levels depending on all the relationships existing between all nodes. However, when working with personal networks, which include an individual's social ties and the ties between those individuals, we mainly use partial networks (Kirke 2007). In this sense, complete networks refer to all ties contained in the relationships of a population, while personal networks (also known as egocentric networks) refer to the ties that specific individuals have. In the latter case, the ties go from egos to their alters. With respect to studies in schools, all participants are usually both potential egos and alters since we usually want to gather complete information about all of the individuals in the network. For a more detailed explanation of social network theory and methods, see Granovetter (1973, 1983) and Lozares (1996).

Social network research is based on the intuitive belief that the structure, or pattern, formed by the relationships in social networks may have an impact on the actions, behaviour, or attitudes of the individuals involved, and that this impact is quite distinct from the attributes of the individuals (Kirke 2007). That is why many studies have analyzed these relationships and their functions as "social support" systems. The nodes to which an individual is connected may be considered as the social contacts of that individual; whereas the network itself can be understood as the value that the individual gets from the social network. The shape of social networks helps determine the usefulness of the networks to its individuals. Tighter networks can be less useful to their members than more open networks with many weak ties in terms of opportunities and access to a wider range of information. Similarly, as we will see later, individuals can bridge networks (called filling structural holes) that are not directly linked if acting as brokers within their social networks. 
In other words, social networks are a good way to measure social capital. Indeed, social capital and networks are frequently seen as synonymous, for example, Lozares (1996) refers to these relational systems in terms of social capital. According to him, networks established among neighbourhoods, associations, communities, schools, and individuals are "relational connections" that make possible (or not) certain processes related to well-being, job placement, inclusive education, participation, the development of a sense of belonging, or coexistence. The concept of "social capital", is derived from the work of the sociologists Pierre Bourdieu (1986) and James Coleman (1990) and over the last decade has become most associated with the work of Putnam (1993). Massey et al. (1987) were the first to apply the concept to migration to explain why and how individual and household decisions are highly dependent on access to the social capital stored in support networks. Presently, social networks are increasingly regarded as important sources of social capital for migrants, allowing them to access social support (Ryan et al 2008).

Social Network Analysis is used from three main theoretical frameworks of social capital that focus on different properties of the network: the theory of the 'strength of weak ties' (Granovetter 1973, 1983), the theory of 'structural holes' (Burt 1992) and the theory of 'social resources' (Lin 1999). These theories are not exclusive because they focus on different parts in the process of accumulating social capital. Granovetter's and Burt's theories focus on the structure of the network, and Lin's theory focuses on the content of the network.

In the first theoretical approach, Granovetter uncovered that linkages determine the usefulness of the network:

"Weak ties, often denounced as generative of alienation (Wirth 1938), are seen as indispensable to individuals' opportunities and to their integration into communities; strong ties, breeding local cohesion, lead to overall fragmentation" (Granovetter 1973: 1378).

"I have not argued that all weak ties serve the functions described in SWT-only those acting as bridges between network segments. Weak ties are asserted to be important because their likelihood of being bridges is greater than (and that of strong ties less than) would be expected from their numbers alone" (Granovetter 1983: 229).

Strong ties, such as relationships with family members, friends or other groups, are seen as "bonding social capital" which creates trusting relationships and sense of belonging. Meanwhile, weak ties are defined as "bridging social capital" which allows the construction of bridges between heterogeneous networks. They increase inclusiveness and facilitate access to resources.

In the second theoretical approach, Burt introduced the argument of structural holes in social networks as the social capital created by a network in which people can broker connections between otherwise disconnected segments. The weaker connections are considered holes in the social structure. However, these structural holes do not mean that individuals are unaware of one another; it only means they do not share the same activities (Burt 1992).

Finally, the third major theoretical approach on social capital is social resources theory (Lin 1990) which focuses on the nature of the resources embedded within the network. Lin and his colleagues argued that it is neither the weakness of the tie nor its bridging properties what conveys advantages to the individual, but the fact that through such ties the resources required for the ego are likely to be reached. Alters are 
considered to be a social resource because they possess characteristics or control resources that are useful for the attainment of the ego's goals.

In short, there are many factors to be examined when it comes to social network analysis: the nature of the relationships between individuals, the social networks formed by those relationships, the patterns of relationships in those social networks, and the consequences for the individuals who are embedded in those social networks (Kirke 2007).

Research in a number of academic fields has shown that the number of empirical studies employing network analysis is rapidly increasing. Network concepts and analysis have been widely used in the social sciences, though they have been rarely applied within the field of intercultural education sociology (Fernández Enguita, Gaete and Terrén 2008). In Spain, social network analysis is being widely used as a diagnostic and comprehensive tool (Sanz Menéndez 2003) which is generating debate on public policy analysis and immigrant integration (Zapata-Barrero et al 2002). Its contribution is helping to add to existing knowledge and revise the nature of discussions about migration.

Using this approach, for instance, Eito (2005) concluded that networks can promote integration; Bonet (2006) explored the relational dimension of social exclusion; and Gracia and Herrero (2006), Maya (2004) and Villalba (2004) have shown the connection between networks and community empowerment. Other interesting studies connected with the migration phenomena focused on the typology of the social support networks that African immigrants have (Martínez García et al 2001a), the buffer effect of social support on depression among immigrants (Martínez García et al 2001b), labour market segmentation and the integration of women (Maya et al 1999), the relationship between personal networks and ethnic self-identification of migrants in Spain (Lubbers, Molina and McCarty 2007), the evolution of personal networks of Argentinean migrants in Spain (Lubbers et al 2009) and the changing patterns of immigrant networks in Catalonia (Molina, Lerner and Gómez 2008).

\section{A new perspective on migration impact in schools: social networks}

We now turn our attention to the following question: how can the use of social network analysis contribute to the development of a more inclusive education?

The first answer comes from Molina (2005) who states that social networks can advance the understanding of social phenomena at a meso-level (Ferrand 2002, de Federico 2002) referring to relational issues. The micro level focuses on the explanatory characteristics and circumstances attached to the person and the macro level centres its attention to the contextual constraints. In Lozares' words (2003), the difference between the meso level and the others (micro or macro) lies in taking social interactions as a starting point to empirically identify structures in which they are embedded. However, we also believe that gaining knowledge about peer-interactions may be valuable when we are dealing with the most appropriate decisions to be made; particularly regarding how relationships can be developed and shaped to enhance both inclusive practices and educational performance in the multicultural environments that characterize today's schools.

Secondly, research on the impact of migration has shown that close relationships between native and non-native individuals leads to inclusion. At a post-secondary level, it has been shown that a close relationship between students and the existence of supportive school dynamics positively affect institutional persistence, personal development, satisfaction, and academic achievement among others (Pascarella and 
Terenzini 1991). It seems fairly clear to us that we need to consider the conditions that are required for those successful contacts to occur, because they increase the chances for academic success. It is our opinion that the social network approach is one of the most appropriate techniques to examine such interactions.

Along these lines, relations based on friendship and cooperation, or simply positive relations among peers, have also been seen as important sources of emotional support for individuals, particularly in cultural groups that have a minority status. Therefore, such relations may once again be considered as authentic bridging strategies towards inclusion. However, the so-called 'contact hypothesis', put forward by Gordon Allport (1954), warns that simple contact between groups is not automatically sufficient to improve intergroup relations. According to him, contact between groups improves intergroup relations only when four prerequisite conditions exist (Dovidio, Gaertner and Kawakami 2003):

(1) equal status within the contact situation;

(2) intergroup cooperation;

(3) common goals; and

(4) support by authorities, law, or custom.

If native and non-native students are all together in the same classroom, this does not imply that their number of links will necessarily increase. As a matter of fact, Fernández Enguita, Gaete and Terrén (2008) showed that because there is a skewed distribution of immigrants across schools there is a certain amount of network "inbreeding" among immigrant students. They conclude that the concentration of immigrants in classrooms leads to increased intra-group bonding practices (for both immigrants and natives), which can be harmful for all. On the other hand, there are some beneficial effects for immigrants since those practices increase their welfare and self-esteem. Given such findings, we need to identify appropriate mechanisms to help students succeed academically and to promote more inclusive practices. Using a sociometric approach to study how the integration of the descendents of immigrant families takes place in school, they found that both exclusion and inclusion are relational notions that refer to the distance or intensity of links between individuals (or nodes) and their unequal access to network resources. This leads back to the usefulness of looking at social networks when studying inclusion. On this basis, as intra-group bonding increases within a group, individuals feel that they are better accepted by the group itself and, at the same time, this pushes them to also include the other group members in their own sense of intra-group belonging. Similarly, if group members have a considerable amount of contacts who are non-group members, there is less exclusion and more acceptance of 'others'. Therefore, students with weaker ties have more opportunities to be excluded. And even with stronger ties, their relations will only be inclusive if they are truly inter-ethnic.

While it is true that relationships among students from different ethnic and racial backgrounds may benefit from a broader appreciation of differences, there are two issues that must be considered. Firstly, pupils often use ethnic background as a criterion in the social selection among the available peers, as noted by Vermeij et al. (2009). Secondly, belonging to a particular group can make the network itself and the group itself carriers of negative capital. This last point usually occurs when individuals with strong ties tend to limit their contacts, opportunities and social mobility. Eito (2005) refers to this phenomenon when referring to the integration of immigrants. According to him, bonding within networks might increase a desire in individuals to be surrounded by peers, rejecting values or norms of others not included in the bonding network. In 
these cases, even weak contacts do not provoke significant change in attitudes (as we shall see now).

Dovidio, Gaertner and Kawakami (2003) found that there is strong agreement across articles regarding the importance of the relationships among contacts, crossgroup friendships, and intergroup attitudes. In general, their findings show that providing opportunities to develop intergroup friendships seems to lead to more positive intergroup attitudes. Likewise, Vermeij et al. (2009) have recently noted that contact with members of other groups can challenge prejudices, lead to a more positive attitude towards other groups and also an enhanced willingness to accept members of this group as friends. Such positive attitudes can act as authentic bridges to build stronger relationships in multicultural classrooms. Indeed, Booth and Ainscow (2002), in their index for inclusion, refer to attitudes as one of the major obstacles to inclusion. Much of their work, which focuses on processes related to inclusive development within educational systems, shows that change, being far from straightforward, depends on pre-existing attitudes and practices.

Finally, educational research has also confirmed the importance of peer-relations on academic performance. As Hartup (1996) has observed, interaction between peers is particularly significant with respect to educational aspiration and academic achievement. His work suggests that friendship studies deserve greater attention, considering the amount of evidence showing that friends provide one another with cognitive and social scaffolding and support positive outcomes across normative transitions. However, rather than knowing whether or not individuals have friends, according to Hartup we need to know who these friends are and understand the quality of relationships between them. Rizzuto et al. (2008), drawing on social network theory, suggest that "who students know" matters in large classrooms. They also claim that in order to better understand human behaviour in educational environments, research must look at psychological, social and infrastructural resources in combination, especially in large groups. Secondly, he reaffirms the idea that social networks determine the amount of social capital one can enjoy. Depending on the information inherent in networks, one will take more or less advantage of the knowledge and skills possessed by others. Along these lines, he gives us a very clear example of how social capital takes place in class. When a student lends lecture notes to an absent classmate, there is a mutual expectation that the favour might be returned in the future. If the favour finally arrives, the social tie between them will be strengthened.

\section{Conclusion}

All the studies above demonstrate that peer-to-peer interactions play a significant role in students' everyday life due to two main reasons: (1) strengthening the social ties between students, especially if they have different backgrounds, leads to inclusion because relationships have a bearing on attitudes, emotions, individual welfare, selfesteem, prejudices and acceptance among others; (2) social networks, understood as sources of social and cultural capital, are powerful bridges and support for students to academically succeed and transit. Social network analysis is an effective method to visualize student connections through exploring relational dynamics. Thus, social and personal networks are essential keys in the analysis and understanding of classroom dynamics between native and non-native students.

To a greater or lesser degree, most people have network connections. The fact that these networks exist creates an excellent starting point regarding efforts to increase interactions among culturally diverse students in order to foster social inclusion. This 
can be achieved by increasing the chances for students to create bridges and links in their already existing networks. One of the ways to achieve this is by promoting opportunities where students can interact with each other.

Rizzuto et al. (2008) have proposed several alternatives: "peer relationships may be facilitated and developed through instructional assignments that: (a) draw upon diverse skill and knowledge sets, (b) reward group collaborations, and (c) encourage peer-to-peer learning. Instructional techniques that build social networks may support performance goals by helping students to access the social and infrastructural resources embedded within their classroom contexts, and thereby overcome some of the disadvantages associated with class size" (Rizzuto et al., 2008: 186).

Stearns (2004) also writes about the influence schools can have on the social atmosphere and levels of interracial friendliness among students. By examining the relationship between student body composition and school organization, she added an understanding of how the manner in which the school is organized influences the formation of strong and weak ties. Some factors that can influence student relationships in terms of school organization are:

(1) school policy and practices,

(2) students' perception of opportunities for interracial contact coming from the school organization,

(3) ethnic composition of schools, and

(4) tracking mechanisms in school systems.

Consequently, although there are still many battles to be fought, the challenge of implementing inclusive education, an issue critical to education systems today, seems more manageable. Fostering student interactions in real inclusive multicultural environments can lay the foundations for further networks to be built, which provide enough social capital to help individuals succeed. The more inclusive future classrooms and schools are, the more social inclusion will develop. After all, what happens in school has an impact on the social fabric of society.

\section{References}

Allport, Gordon W. (1954). The nature of prejudice. Cambridge, MA: Addison-Wesley.

Bonet, Jordi (2006). La vulnerabilidad relacional: análisis del fenómeno y pautas de intervención. REDES. Revista Hispana para el Análisis de Redes Sociales, 11 (4): Available in: http://www.raco.cat/index.php/Redes/article/view/53176/61149

Booth, Tony and Ainscow, Mel (2002). Index for inclusion: developing learning and participation in schools. Bristol: CSIE.

Bourdieu, Pierre (1986). "The Forms of Capital". In Richardson, J.G. (ed.) Handbook of Theory and Research for the Sociology of Education. New York: Greenwood.

Burt, Ronald S. (1992). Structural Holes: The Structure of Competition. Cambridge, MA: Harvard University.

Coleman, James S. (1990). Foundations of social theory. Cambridge, MA: Harvard University Press.

Dovidio, John F., Gaertner, Samuel L., and Kawakami, Kerry (2003). Intergroup contact: The past and the future. Group Processes and Intergroup Relations, 6: 5-21. 
Eito, Antonio (2005). Las redes sociales y el capital social como una herramienta importante para la integración de los inmigrantes. Acciones e Investigaciones Sociales, 21: 185-204.

Fernández Enguita, Mariano; Gaete, José M. and Terrén, Eduardo (2008). ¿Fronteras en las aulas? Contacto transcultural y endogamia en las interacciones del alumnado. Revista de Educación, 345: 157-181.

Freeman, Linton C. (2004) The Development of Social Network Analysis: A Study in the Sociology of Science. Vancouver: Empirical Press.

Gracia, Enrique and Herrero, Juan (2006). La comunidad como fuente de apoyo social: evaluación e implicaciones en los ámbitos individual y comunitario. Revista Latinoamericana de Psicología, 38 (2): 327-342.

Granovetter, Mark (1983). The strength of weak ties: A network theory revisited. Sociological Theory, 1: 201-233.

Granovetter, Mark (1973). The Strength of Weak Ties. American Journal of Sociology, 78: $1360-80$.

Hartup, Willard W. (1996). The company they keep: Friendships and their developmental significance. Child Development, 67: 1-13.

Kirke, Deirdre M. (2007) Social network analysis and psychological research. The Irish Journal of Psychology, 28 (1): 53-61.

Lin, Nan (1999). Building a network theory of social capital. Connections, 22 (1): 2851.

Lozares, Carlos (1996). La teoría de redes sociales. Papers, 48: 103-126.

Lozares, Carlos (2003). "Valores, campos y capitales sociales". REDES. Revista Hispana para el Análisis de Redes Sociales, 4 (2). Available in: http://revistaredes.rediris.es/volumen-especial/vol4_2.pdf

Lubbers Miranda J., Molina, José L., Lerner, Jürgen, Brandes, Ulrik, McCarty Christopher and Ávila, Javier (2009). Longitudinal analysis of personal networks. The case of Argentinean migrants in Spain, Social Networks, 31 (5): 46-57.

Lubbers, Miranda J., Molina, José L. and McCarty, Christopher (2007). Personal Networks and Ethnic Identifications: The Case of Migrants in Spain. International Sociology, 22 (6): 720-740.

Martínez García, Manuel F., García Ramírez, Manuel and Maya, Isidro (2001a). Una tipología analítica de las redes de apoyo social en inmigrantes africanos en Andalucía. Revista Española de Investigaciones Sociológicas, 95: 99-125.

Martínez García, Manuel F., García Ramírez, Manuel and Maya, Isidro (2001b). El efecto amortiguador del apoyo social sobre la depresión en un colectivo de inmigrantes. Psicothema, 13 (4): 605-610.

Massey, Douglas S.; Alarcon, Rafael; Durand, Jorge and González, Humberto (1987). Return to Aztlan: the social process of international migration from Western Mexico. Berkley: University of California Press.

Maya Jariego, Isidro, Martínez, Manuel F., and García, Manuel (1999). Cadenas migratorias y redes de apoyo social de las mujeres peruanas en Sevilla. Demófilo: Revista de Cultura Tradicional de Andalucía, 29: 87-105. 
Maya, Isidro (2004). Sentido de comunidad y potenciación comunitaria. Apuntes de Psicología, 22(2): 187-211.

Molina, José L. (2005) El estudio de las redes personales: contribuciones, métodos y perspectivas. Empiria. Revista de Metodología de las Ciencias Sociales, 10: 71-106.

Molina, José L., Lerner, Jürgen and Gómez, Silvia (2008). Patrones de cambio de las redes personales de inmigrantes en Cataluña. REDES. Revista hispana para el análisis de redes sociales, 15 (4): 36-60.

Pascarella, Ernest T. and Terenzini, Patrick T. (1991). How college affects students: Findings and insights from twenty years of research. San Francisco: Jossey-Bass.

Putnam, Robert D. (1993) The prosperous community: social capital and public life. American Prospect, 4: 13.

Rizzuto, Tracey E., LeDoux, Jared, and Hatala, John P. (2009). It's not just what you know, it's who you know: testing a model of the relative importance of social networks to academic performance. Sociological Psychology Education, 12: 175-189.

Ryan, Louise; Sales, Rosemary; Tilki, Mary and Siara, Bernadetta (2008) Social networks, Social support and Social capital: The experience of recent Polish migrants in London. Sociology, 42 (4): 672-690.

Sanz Menéndez, Luis (2003). Análisis de redes sociales: o cómo representar las estructuras sociales subyacentes. Apuntes de Ciencia y Tecnología, 7: 21-29.

Stearns, Elizabeth (2004) Interracial Friendliness and the Social Organization of Schools. Youth Society, 35 (4): 395-419.

UNESCO (2001) The Open File on Inclusive Education. Paris: UNESCO.

Vermeij, Lotte, van Duijn, Maritjtje A.J. and Baerveldt, Chris (2009). Ethnic segregation in context: social discrimination among native Dutch pupils and their ethnic minority classmates. Social Networks, 31(4): 230-239.

Villalba, Cristina (2004). La perspectiva ecológica en el trabajo social con infancia, adolescencia y familia. Portuaria, 4: 287-298.

Zapata-Barrero, Ricard, Adamuz, Carles and Martínez, Isabel (2002). Estructuras institucionales y redes de actores en las políticas de acomodación y cambio structural (Paper). Lisboa (Portugal): VII Congreso Internacional del CLAD sobre la Reforma del Estado y de la Administración Pública. 